\title{
Aspectos do comportamento reprodutivo na monta natural de eqüinos da raça Crioula*
}

\author{
CHRISTINA CANTO DE FREITAS
}

Rodrigo Costa Mattos (Orientador - UFRGS)

Banca: Ricardo Macedo Gregory (UFRGS), Carlos Antônio Mondino Silva (UFSM), Marc Roger Jean Marie Henry (UFMG)

O presente experimento objetivou verificar o comportamento sexual de três garanhões da raça Crioula, a campo, com idades de 4, 8 e 18 anos frente a uma população de éguas em cio com diferentes idades e status reprodutivo e identificar o papel da fêmea em relação às interações pré-copulatórias. Para tanto foram utilizados três garanhões e 60 éguas, da Raça Crioula, 20 para cada garanhão, com idades variando entre três e 17 anos. As observações foram realizadas durante a estação de monta, tendo início em quatro de novembro de 2003 e término em 13 de janeiro de 2004. Cada manada foi observada de cada vez, acompanhada, diariamente por um observador. Em primeiro lugar foi observado o garanhão G8 e sua manada, por nove dias, seguido pelo G18 observado por oito dias, e G4 observado por 8,5 dias. Considerando-se os três reprodutores, o número total de horas de observação foi de 256,5 horas, divididas em dois turnos, manhã e tarde, com uma média de 5,4 horas de observação no turno da manhã e 4,64 horas no turno da tarde, Foram observadas e registradas, através de anotações e fotografias, todas as atitudes do garanhão, relacionadas com o seu comportamento sexual perante as éguas, assim como as atitudes das mesmas perante os reprodutores. O acompanhamento dos animais pelo observador era feito a pé, com a maior descrição para não interferir no comportamento e na disposição da manada e quando necessário, era utilizado um binóculo. Houve o cuidado de não permitir a presença de outros eqüinos nos piquetes vizinhos aos que as manadas observadas permaneciam, para que não houvesse nenhum tipo de interferência no comportamento dos animais. Os garanhões permaneceram com as éguas por todo o tempo do experimento, inclusive no período da noite. Concluiu-se que a atividade sexual diminui com o aumento da idade do garanhão. As éguas falhadas em cio formam o grupo sexualmente ativo, permanecendo mais próximas ao garanhão do que éguas em cio com cria. A rufiação e o momento da cobertura são determinados pelo garanhão. O número de coberturas diminuiu com o passar dos dias, havendo regulação por parte do garanhão, mesmo com um elevado número de éguas em cio por dia. Houve um elevado índice de prenhez em relação às coberturas realizadas no cio observado.

Descritores: eqüinos, crioulo, comportamento sexual, garanhões.

Apresentada: 23 março 2005

"Dissertação de Mestrado n.407 (Especialidade: Fisiopatologia da Reprodução). 59f. Programa de Pós-graduação em Ciências Veterinárias [www.ufrgs.br/ppgcv], Faculdade de Veterinária, Universidade Federal do Rio Grande do Sul (UFRGS), Porto Alegre/RS. CORRESPONDÊNCIA: C.C.Freitas [ccantofreitas@ibest.com.br]. 


\title{
Aspects of sexual behavior of natural breeding in Criollo horses ${ }^{* *}$
}

\author{
CHRISTINA CANTO DE FREITAS
}

\author{
Rodrigo Costa Mattos (Adviser - UFRGS)
}

Committee: Ricardo Macedo Gregory (UFRGS), Carlos Antônio Mondino Silva (UFSM), Marc Roger Jean Marie Henry (UFMG)

The present experiment aimed to verify the sexual behavior on pasture of three Crioulo Breed stallions, ageing 4,8 and 18 years old, face to a population of mares in heat with different ages and reproductive status and identify the female role in relation to the pre-coupling interactions. Therefore three stallions were used, as well as 60 Crioulo mares, 20 for each stud, ageing between 3 and 17 years old. Observations were made during breeding season, from November $4^{\text {th }}, 2003$, through January $13^{\text {th }}$, 2004. Every day, each herd was watched separately. Primarily, stallion G8 and his herd were observed for 9 days, followed by G18 for 8 days and G4 observed for 8,5 days. Considering the three stallions, the amount of observation time was of 256,5 hours, split in morning and afternoon shifts. Mean observation time was of 5,4 hours in the morning shift and 4,64 hours in the afternoon shift. Notes and pictures were taken to register all the attitudes of the studs, related to their sexual behavior face to the mares, as well as the mares' attitudes face to the stallions. Watching periods were made on foot, with most discretion for not to interfere on behavior or the herd arrangement, and when necessary a binocular was used. Other horses were not allowed next to the observation pasture, so that no kind of interference could be made. The stallions remained with the mares for all the time during the experiment, even at night. It was found that sexual activity reduces while the age of the stallion increases. Barren mares in heat compose the sexually active group, remaining closer to the stud than the foaling mares in heat. The stallion determines teasing and the moment of the coupling. The number of mountings decreases as days go by, being regulated by the stallion, even with a high number of mares in heat per day. There was a high pregnancy rate with regard to the mountings made in the observed heat periods.

Key words: equine, crioulo breed, sexual behavior, stallion. 